\title{
The Changes of The Village Head Election System For The Implementation Of Village Government
}

\author{
Affila $^{1}$, Afnila $^{2}$, Armansyah $^{3}$ \\ Fakultas Hukum,Universitas Sumatera Utara, Indonesia ${ }^{1,2,3}$ \\ affila75@ymail.com
}

\begin{abstract}
The history of village governance has changed along with the dynamics of conditions and the national political situation. The village is the center of the local community which has autonomy in managing community life, local institutions and economic resources. Law No. 6 of 2014 concerning Villages, that the Village Head is directly elected by the villagers, Republic of Indonesia citizens who meet the requirements. Although, the regulation on the selection of village heads from time to time has changed, it is not a fundamental change. Because the village head election system from the past until now remains the same that is elected by the people directly. Existing regulations will continue to have a significant impact in the implementation of the election of Village Heads which will or have been carried out directly and simultaneously in the Regency/City, the implementation of which is regulated by Regency / City Regional Regulations. In this research using the normative juridical method, it was found that the village head election system had previously implemented a direct election system by the people, but experienced various influences on the pattern of governance, development and empowerment of village communities by the village head.
\end{abstract}

Keyword : village head, village head election system, implementation of village government

\section{Introduction}

The fact shows that the majority of Indonesian citizens still live in the village. Thus, the population of the village is a basic capital for national development, which is owned by Indonesia. The population of village is very large, if it can be developed well, is an effective workforce for various development activities in all fields of life community.Therefore, the village needs the most attention for increased development, especially through increasing community initiatives and self-sufficiency. People in the village have positive aspects that can be developed in the context of development is the spirit of mutual cooperation, discussion and family spirit for development. According to the U.S. Kesuma,The village strength with its personality and character that can survive, because of two factors, that : (M.Solly:1983)

a. Obedience of all residents (inclined to obey).

b. Being submissive and filial to the ancestors (respecting fair power and being seen as wise). 
Both of conceptually and operationally, governance and village development are in national programs. Village government is a mechanism for implementing governmental power which is responsible for development in the village. According to Mashuri Maschab, when talking about villages in Indonesia, then it will at least lead to three kinds of interpretation or understanding. The First, the sociological sense that describes a form of unity of people who live and settle in an environment where between them know each other well and their life style is relatively homogeneous, and much depends on the benefits of nature. In this sociological sense, the village is associated with a community that lives simply. Second, understanding economically, the village as a community environment that is trying to meet the daily needs of life from what is provided by the natural surroundings. Third, political understanding, where the village as a government organization that politically has a certain authority because it is part of the government. In this sense, villages are often formulated as a legal community unit that is in charge of organizing self-government. Thus, it cannot be denied that the village is the front gate of the Republic of Indonesia's government system, where its existence is the spearhead of the implementation of democratization. The practice of implementing village governance is a reflection of democracy in our government. The regulations on village governance continue to change. The position of the village government in its constellation with the practice of decentralization and regional autonomy was only apparent after the Law No. 32 of 2004 concerning Regional Government, which placed the village government as part of the district government. The final regulation governing village government is the Law No. 6 of 2014. Indonesia has redistributed resources and given a mandate in the form of authority and development to villages that first made a full recognition and respect as written in Law No. 6 of 2014 concerning Villages. The Ministry of Villages, Development of Disadvantaged Regions, and Transmigration of the Republic of Indonesia welcomed the birth of the law as a starting point for the re-birth of a new village, as well as a moment to throw away the old village paradigm. In an effort to create a village government as an orderly regulator of government and village development, it is necessary to have a village administration device that is capable, authoritative, dynamic and accompanied by good administrative management in accordance with the times. Because the function of the Village Head is very decisive, therefore a candidate elected as Village Head is not just a person who receives the most votes in the election, but is a developments and modernist. Thus, a candidate elected as Village Head in addition to meeting the acceptability requirements must also meet the capability requirements.

A village head must be able to :

a. carring out government and development tasks in the village.

b. accommodating and solving all problems that arise in the village

c. grow positive results that have been achieved in a more perfect direction.

The Village Head is a citizen of the Republic of Indonesia who is elected directly from and by villagers directly from and by local villagers.

In Law No. 6 of 2014 determined that: 
1. Election of Village Heads is held simultaneously in all Districts / City.

2. The Districts / City Regional Government determines the policy on the simultaneous election of the Village Heads as referred to in verse (1) with the Regulations of the Districs / City Region.

3. Further provisions regarding the procedure for the selection of concurrent Village Head as referred to in verse (1) and verse (2) shall be regulated in a Ministerial regulation based on Government Regulation.

\section{RESEARCH METHODS}

The research method used is empirical normative research. Empirical (applied) normative legal research examines the factual implementation and implementation of positive legal provisions in any particular legal event. The study aims to ascertain whether the results of the application of the inconcreto legal event are in accordance with or not the provisions in the Law. There are two stages in empirical normative law research. The first stage is to study normative law, namely the Law on Villages, Government Regulations and Regulations of the Minister of the Interior and Regional Regulations, as well as Regional Regulations. The second phase is to study empirical law in the form of implementation of legal events, in this case relating to the election of the Regional Head. The study was conducted in the Pagar Marbau Sub-District, Deli Serdang District, North Sumatra Province. We chose Deli Serdang District because this district has quite a large number of village government and has held elections for the Village Head simultaneously in accordance with the mandate of Law No. 6 of 2014.

\section{REGULATION REGARDING VILLAGE}

Both conceptually and operationally, governance and rural development are in one national problem and program. Thus, village government is a mechanism for implementing governmental power which is responsible for development in the village. Instead the village government is one part of the contents in the development movement in the village.During the New Order era, based on The Law Number 5 of 1979 concerning Village Government, the village government system was based on the village patterns in Java. Villages outside Java were abolished. According to the explanation of The Law No. 5 of 1979 concerning Village Government, the aim of uniformity is to facilitate coaching. As a result, uniformity has a negative impact.The Law Number 5 of 1979 was then replaced by The Law Number 22 of 1999 which then mention of the village may be with another name, as well as the apparatus..The Law Number 32 of 2004 wants to re-equate the term "Village" for all the lowest forms of government in the Unitary State of the Republic of Indonesia. Other names such as "Nagari" in West Sumatra, "Gampong" in Nanggroe Aceh Darusalam, "Lembang" in South Sulawesi, "Kampung" in South Kalimantan, and "Negeri" in Maluku, with the enactment of Law Number 32 Year 2004 subsequently uniformly called "Village". However, the State still recognizes and respects the customary law community units, along with traditional rights as long as they are still alive and in accordance with the development and principles of the Unitary State of the Republic of Indonesia.Next, there is a desire to 
make a new Village Law. The law will regulate individual village issues, such as Law Number 5 of 1979. This is because the law governing village issues has several weaknesses. Research conducted by the Yogyakarta IRE team stated that the failure of policies and regulations on villages was caused by: First, the paradigm error in the village; Second, the wrong orientation about the village; Third, there are centralized policies and regulations on villages; Fourth, various village development policies and programs are not implemented in a sustainable manner; Fifth, the sectoral approach adopted mostly fails to create integration and synergy in development policy. Almost all fractions in the DPR and the government in the process of discussing the Village Law allude to the failure of the old legislation and the need for a new regulation on villages. This new regulation is a correction of the mistakes of the old rules as well as an anticipation for changes in the future.According to Gamawan Fauizi (Minister of Home Affairs at the time), through a Government Statement dated April 2, 2012 conveyed the urgency of the Village Law as follows: The Law on Villages aims to elevate the village to an honorable subject position in the constitution of the Republic of Indonesia. The Village Setting will determine the right Village format in accordance with the context of local diversity. The Law on Villages actually also puts Villages as the subject of government and development that really departs from the bottom. At present, the village goverment is entering a new phase with the enactment of Law No. 6 of 2014 concerning Villages. There are six main passions in this law, namely, respect for diversity, the legal umbrella of village governance, giving direct budgets to villages, participatory budgeting, opening opportunities to open businesses through village-owned enterprises, and encouraging technology transfer processes.

\section{AUTHORITY AND SELECTION OF THE VILLAGE HEAD}

The Law of Local government recognizes village autonomy or by other names, and village governments can be given assignments or delegations from the government or regional government to carry out certain government affairs. As for villages outside of geneological villages, namely villages that are administrative in nature such as villages formed due to village expansion or due to transmigration or for other reasons whose citizens are pluralistic, pluralistic or heterogeneous, then village autonomy is given the opportunity to grow and develop following the development of the village. Paragraph 18 of The Law Number 6 of 2014 states that village authority encompasses authority in the areas of administering Village Government, implementing Village Development, fostering village community, and empowering village communities based on community initiatives, original rights, and village customs. Paragraph 19 states that the Village Authority includes: :

Authority based on original rights; Local authority of the village; Authority assigned by the Government, Provincial Government, or District / City Government; and Other authorities assigned by the Government, Provincial Governments, District/City Governments are in accordance with statutory provisions. The authority stated in The Law Number 6 of 2014 looks better and broad in meaning when compared to the previous the Law ( The Law No. 5 of 1979, The Law No. 22 of 1999, and The Law No. 32 of 2004). The Village Government Administrators are Village Heads who are assisted by village officials. The village head is in charge of carrying out village governance, carrying out village development, village community development, and village community empowerment. In carrying out their duties the Village Head is authorized to: a, lead the administration of the village administration; b, lifting and stopping village officials; $c$, holds the power to manage 
Village Finances and Assets; d, establishing Village Regulations; e, determine the village budget and income; f, fostering village community life; g, fostering peace and order of the village community; $h$, fostering and improving the village economy and integrating in order to achieve a productive scale economy for the greatest prosperity of the village community; $\mathrm{I}$, developing sources of village income; $\mathrm{j}$, proposing and accepting the transfer of a portion of the country's wealth to improve the welfare of rural communities; $\mathrm{k}$, develop the social cultural life of the village community; 1, utilizing appropriate technology; $\mathrm{m}$, coordinating participatory Village Development; $n$, represent the Village inside and outside the court or appoint a legal representative to represent it in accordance with statutory provisions; and o, exercising other authorities in accordance with statutory provisions. The tasks and authorities regulated in Paragraph 26 of The Law Number 6 of 2014 are detailed and cleared, so that the Village Head has complete instructions in carrying out his duties and authority. In carrying out its tasks and authorities, the Village Head is obliged to: a, uphold and practice the Pancasila, implement the 1945 Constitution of the Republic of Indonesia, and maintain and preserve the integrity of the Unitary State of the Republic of Indonesia, and Bhinekha Tunggal Ika; b, improve the welfare of the village community; c, maintaining the peace and order of the village community; $d$, obey and enforce the laws and regulations; e, carrying out democratic life and gender life; f, implement the principles of Village Governance that are accountable, transparent, professional, effective and efficient, clean and free from collusion, corruption and nepotism; g, establish cooperation and coordination with all stakeholders in the village; $h$, organizing good village government administration; I, managing finances and Village Assets; j. carry out government affairs which become the authority of the Village; $\mathrm{k}$, resolve community disputes in the village; 1 , developing the economy of the village community; $\mathrm{m}$, fostering and preserving the social cultural values of the Village; $\mathrm{n}$, empower communities and social institutions in the village; o, developing natural resource potential and preserving the environment; and, $\mathrm{p}$, provide information to the village community. In accordance with the above provisions, the Village Head is the first person to have a heavy duty and obligation, because he is the main organizer and responsible in the fields of government, development, community, fostering peace and order, developing the potential of natural resources and so on. Thus, the village head must be someone who has the ability and has the support of the community. The Village Head based on the Village Law stipulates that the Village Head must be directly elected by the people. In carrying out its duties and authorities, the Village Head must: a, submit a report on the administration of the Village Government at the end of the fiscal year to the Regent / Mayor; b, submit a report on the administration of the village Government at the end of the term of office to the Regent / Mayor; c, provide a written report on government administration to the Village Consultative Body at the end of the fiscal year, and d, provide and/or disseminate information on government administration in writing to the village community at the end of the fiscal year. The Election of Village Heads is held simultaneously in all regencies / cities. The District / City regional government determines the policy of implementing village head elections simultaneously with District / City regional regulations.. In Paragraph 40 of Government Regulation No. 43 of 2014 concerning Regulations for Implementation of Law Number 6 of 2014 concerning Villages, it is determined that simultaneous village head elections can be held at most 3 (three) times within a period of 6 (six) years. If there is a vacancy of the village head's position in the simultaneous election of the village head, the Regent / Mayor may appoint an official of the village head. The village head officials are from civil servants within the district / city government. 
In Paragraph 33 of The Law Number 6 of 2014, determines that candidates for Village Heads must fulfill the following requirements:Citizen of the Republic of Indonesia,Devoted to God Almighty,Upholding and practicing Pancasila, implementing the 1945 Constitution of the Republic of Indonesia, and maintaining and maintaining the integrity of the Unitary Republic of Indonesia and Unity in Diversity, The lowest educated graduate of junior high school or equivalent, The lowest age is 25 (twenty five) years when registering, Willing to be nominated as Village Head,Registered as a resident and residing in the local village at least 1 (one) year before registration,Not serving a prison sentence, Never been sentenced to imprisonment based on a court decision that has permanent legal force for committing an offense threatened with imprisonment for at least 5 (five) years or more, except 5 (five) years after finishing serving a prison sentence and announcing honestly and openly to the public that the person concerned has been convicted and not as a perpetrator of repeated crimes, Not being revoked of his right to vote in accordance with a court decision that has permanent legal force,Healthy body, Never as Village Head 3 (three) times in office, and Other requirements stipulated in the Regional Regulation

\section{THE ELECTION OF VILLAGE HEAD OF DELI SERDANG DISTRICT}

To implement the provisions of paragraph 31 of The Law Number 6 of 2014, and paragraph 40 of Government Regulation Number 43 of 2014, Deli Serdang District Regulation No. 2 of 2015 concerning the Election of Village Heads. The Election of Village Heads in Deli Serdang Regency is carried out in the form of: 1, The Election of Village Heads simultaneously or can be wavy; and 2, The Election of Village Heads from time to time through village deliberations. The Village Head Elections in waves, are village head elections held on the same day taking into account: a, the grouping of the term of office of the Village Head in the District, b, the financial capacity of the District Government, and / or c, the availability of civil servants within the District fulfill the requirements as an official of the Village Head. In the event of a vacancy in the position of Village Head in the holding of a simultaneous or wavy osf The Village Head Election, the Regent shall appointed an Acting Village Head. The simultaneous election of Village Heads is carried out through stages: a, preparation, b, nomination, c, voting, d, determination. The candidates for Village Heads must meet the requirements stipulated in the existing Laws and Regulations, in Article 22 of Regional Regulation of Deli Serdang Regency Number 2 of 2015, determine: 1, the nominees nominated as Village Candidates shall be at least 2 (two) people and at most 5 (five) people; 2, Prospective candidates who have fulfilled the requirements as referred to in verse (1) shall be announced to the public to obtain input; 3 , Candidates who have fulfilled the requirements can be determined as candidates for the Village Head by the election committee; 4, In the case of prospective candidates who meet the requirements of less than 2 (two) people, the election committee extends the registration period for 20 (twenty) days; 5, If an extension of the registration period has been held as referred to in paragraph (4), prospective candidates who meet the permanent requirements of less than 2 (two) people, then the Regent postpones the implementation of the election of the Village Head until the time of holding the election of the Village Head simultaneously in the next wave; 6, to fill the vacancy of the position of Village Head due to the postponement of the Village Head Election, the Regent appoints an official Village Head from the Civil Servants within the Regency Government; 7, in the case of prospective candidates who meet the requirements, more than 5 (five) people are selected by the committee determined by the Regent's Decree; 8 , selection using criteria of work experience 
in government institutions, education, age and selection of written examinations; 9, determining the selection results of the committee submitted to the Regent to be subsequently submitted to the selection committee through the Camat. By looking at the provisions above, it appears that a single candidate is no longer possible in the election of the Village Head. This is different from the election of a Regional Head which allows for a single candidate. It is possible for candidates for Village Heads to emerge more than 5 (five) people, this is because to nominate themselves there is no requirement of support from the community, it is better to determine the conditions of support from the community to limit candidates who nominate themselves. In connection with the determination of candidates determined as follows: The election committee determines the Candidates for Village Heads who are entitled to be elected by a decision letter from the Election Committee. The determination of the candidates for village heads is accompanied by the determination of the serial number which is carried out through an open lottery by the election committee and is attended by the candidates. Serial numbers and names of candidates that have been determined are compiled in the list of candidates and set forth in the minutes of the determination of the candidates for village heads. The election committee announces through the bulletin board and / or mass media about the names of the candidates that have been determined, no later than 7 (seven) days from the date of stipulation. The announcement as referred to in verse (4) is final and binding. After determining the village head candidate, the day and date of the vote will be determined, in this case the Regent decides. The village head is directly elected in the election service by the voters. The election of village heads is direct, public, free, confidential, honest and fair. If it is noted that the voting, day and date are determined by the Bupati, this shows that the election committee lacks authority, and is less independent. Whereas the principle used in village village election is the same as the principle of general election, both the election of representative institutions or the election of President and Vice President. Regarding the determination of elected village head candidates regulated in Article 35 of the Deli Serdang Regency Regulation Number 2 of 2015, namely: Candidates for Village Heads who obtain the most votes from the number of valid votes are determined by the Election Committee as the elected Village Head candidate. In the event that there are more than 1 (one) nominee of Village Head candidates who obtain the same majority of votes, the elected Village Head candidate shall be determined based on the acquisition of the highest number of votes in the distribution of hamlets. The selection of Village Heads can be done simultaneously, but it is also possible to elect Village Heads from time to time. Election of Village Heads is regulated further in Regents Regulations, is The Deli Serdang Regents Regulation No. 1830 2016. The process of selecting interim Village Heads regulated in Regulations is almost the same as the process of selecting Village Heads simultaneously or in waves arranged in Regional Regulations. The simultaneous election of Village Heads as mandated by Law Number 6 of 2014, and the implementing regulations have been carried out by Deli Serdang Regency. The election was conducted on December 12, 2017, which was attended by 19 (nineteen) subdistricts, and 76 (seventy-six) villages, as well as 240 (two hundred and forty) candidates. In every village there are 2 (two) candidates people, which is the minimum number of candidates, but there are also candidates consisting of 5 (five) people, which is the most requirement for participating in the election. The simultaneous election of the Village Head has proceeded safely, and peacefully, all parties accepted the results of the election. Candidates for the elected village head have been appointed and carry out their duties. 


\section{CONCLUSION}

From the description above, conclusions can be drawn as follows: Both conceptually and operationally government and village development are included in the national program The village is the frontline of the government system Republic of Indonesia, where its existence is the spearhead of implementation democracy. The village has an important role in the implementation of governance and development, thus the village must be led by someone who owns it the ability to advance the village, and must have the support of the people through direct election. The setting of the village underwent continuous changes, but the changes were done is not too basic, in Law Number 6 of 2014 regarding the Village it is determined that the election of the Village Head shall be held simultaneously at every Regency and City. Deli Serdang Regency has held a village election simultaneously in the Year 2016 and 2017. With the existence of regional regulations to carry out elections Village Head, Village Head Election can be carried out well.

\section{ACKNOWLEDGEMENTS}

This research was funded by Universitas Sumatera Utara in according with TALENTA Universitas Sumatera Utara Research Contract Year of Fiscal 2019.

\section{REFERENCES}

M. Solly Lubis, (1983) Development of Political Lines and PeruUan Local Government, Bandung, Alumni, p.315.

Mashuri Maschab, in, Sirajuddin and Winardi, (2015), Fundamentals of Indonesian Constitutional Law, Malang.

Message from the Minister of Villages, Development of Disadvantaged Regions, and Transmigration of the Republic of Indonesia, (2019), Fajlurrahman Jurdi, Indonesian Constitutional Law, Jakarta, Kencana.

Minister of Home Affairs Regulation No. 1 of 1978, concerning Election, Endorsement, Appointment, Temporary Dismissal and Dismissal of Village Heads.

Titik Tutik Quarter, (2010.) Construction of Indonesian Constitutional Law Post Amendment to the 1945 Constitution, Jakarta, Kencana

Law Number 6 of 2014, concerning Villages,

Regional Regulation of Deli Serdang Regency Number 22015

Report on the implementation of the Election of Serentak Village Head in Deli Serdang Regency. 